\title{
ANALISA KEKUATAN TARIK HOOK SEBAGAI PERANCANGAN OVERHEAD CRANE DENGAN MENGGUNAKAN SOFTWARE AUTODESK INVENTOR
}

\author{
SLAMET RIYADI ${ }^{1} \&$ RIO DARMAWAN ${ }^{2}$ \\ ${ }^{1,2}$ Program Studi Teknik Mesin, Fakultas Teknik, Universitas Muhammadiyah Tangerang \\ Jl. Perintis Kemerdekaan I/33 Cikokol-Tangerang \\ Email : slametriyadi@gmail.com
}

\begin{abstract}
Abstrak
Perkembangan teknologi banyak menciptakan alat yang bertujuan untuk memudahkan pekerjaan manusia, serta dapat meningkatkan kualitas dan kuantitas produksi. Terutama untuk alat pengangkat salah satunya adalah OverHead Crane yang merupakan suatu alat yang berfungsi untuk mengangkat, menurunkan dan memindahkan barang yang dapat digerakkan secara vertikal maupun horizontal yang bisa dioperasikan dengan menggunakan tangan (manual) atau dengan Remote Control (Otomatis). Pengujian tarik merupakan salah satu pengujian material yang paling banyak dilakukan Karena pengujian ini terbilang yang paling mudah dan banyak data yang bisa diambil dari pengujian ini. Diantaranya adalah kekuatan tarik (Ultimate Tensile Strenght), kekuatan luluh (Yield Strenght or Yield Point), keuletan (Ductility), modulus elastis dari material, kelentingan dari suatu material dan ketangguhan (Hardness). Seiring dengan berkembangnya teknologi banyak juga muncul software yang bisa melakukan simulasi uji tarik, salah satunya adalah Autodesk Inventor. yang dirancang khusus untuk keperluan bidang Teknik seperti desain produk, desain mesin, desain mold dan simulasi Stress Analysis. Berdasarkan hasil pengujian kekuatan material FCD-50 untuk pembuatan hook pada alat uji tarik langsung diketahui tegangan maksimum yaitu pada spesimen 2 dengan beban tarik $78.75 \mathrm{kN}$, kuat tarik $643.1 \mathrm{~N} / \mathrm{mm}^{2}$ dan6.555 Kgf $/ \mathrm{cm}^{2}$. Sedangkan untuk mengetahui hasil dari uji tarik spesimen material FCD-50 sebagai langkah awal pendesainan hook crane yaitu dengan cara melakukan simulasi uji tarik menggunakan software Autodesk Inventor didapatkan tegangan maksimum dengan beban tarik $78.75 \mathrm{kN}$ dengan kekuatan $943.249 \mathrm{~N} / \mathrm{mm}^{2}$ dan $96165 \mathrm{Kgf} / \mathrm{Cm}^{2}$
\end{abstract}

Kata kunci : Overhead Crane, Uji Tarik, Hook, FCD-50, Autodesk Inventor, Stress Analysis

\section{Pendahuluan}

Perkembangan teknologi banyak menciptakan alat yang bertujuan untuk memudahkan pekerjaan manusia, serta dapat meningkatkan kualitas dan kuantitas produksi. Terutama untuk alat pengangkat, karena alat pengangkat adalah hal yang sangat penting untuk menunjang suatu pekerjaan, semakin berkembangnya industri semakin berkembang pula kebutuhan alat pengangkat mulai dari yang sederhana sampai yang menggunakan teknologi mesin otomatis.

Di wilayah tangerang banyak sekali perusahaan, khususnya perusahaan industri alat berat yang didalam produksinya menggunakan peralatan pengangkat dengan bentuk dan kekuatan daya angkat yang disesuaikan dengan letak dan kebutuhan. Beberapa perusahaan yang memanfaatkan teknologi alat pengangkat dalam suatu pekerjaan antara lain: perusahaan bongkar muat pelabuhan, industri konstruksi bangunan gedung, industri reparasi pesawat terbang dan kereta api, industri otomotif dan masih banyak lagi. Salah satu sarana alat pengangkat yang banyak kita jumpai di suatu industri adalah OverHead Crane.

OverHead Crane merupakan suatu alat yang berfungsi untuk mengangkat, menurunkan dan memindahkan barang yang dapat digerakkan secara vertikal maupun horizontal yang bisa dioperasikan dengan menggunakan tangan (manual) atau dengan Remote Control (Otomatis). Dengan alasan lebih efisien, banyak perusahaan yang menggunakan Over Head Crane dengan sistem kendali otomatis untuk menunjang pekerjaan yang ada di perusahaan tersebut.

Pesawat udara memiliki dua jenis jendela berdasarkan letak pemasangannya, yaitu Over Head Crane memiliki komponen utama yang disebut dengan Hook (Kait) dimana komponen ini berfungsi sebagai pengait yang mehubungkan beban pada crane. Ada beberapa jenis kait yang umum digunakan oleh banyak perusahaan yaitu: kait tunggal, kait tanduk ganda dan Shackles. 
Di era yang serba komputerisasi ini banyak pengembang yang memanfaatkan teknologi ini untuk menyatukan ilmu matematika, teknik dan komputer sehingga menghasilkan software seperti Autodesk Autocad, Autodesk Inventor dan Ansys. Dari software ini dapat di desain bentuk kait sehingga sesuai dengan kapasitas angkat dan beban yang diberikan. Karena kait harus dirancang dengan memperhitungkan secara detail dari segi fungsi, material, bentuk dan faktor keamanannya. Sehingga perlu dilakukannya simulasi menggunakan software Autodesk Inventor agar kontruksi yang dibuat untuk kait tidak mengalami kegagalan.

\section{Metode Penelitian}

\subsection{Uji Tarik}

Pengujian tarik merupakan salah satu pengujian material yang paling banyak dilakukan di dunia industri. Karena pengujian ini terbilang yang paling mudah dan banyak data yang bisa diambil dari pengujian ini. Diantaranya yang bisa didapat dari pengujian tarik ini adalah kekuatan tarik (Ultimate Tensile Strenght), kekuatan luluh (Yield Strenght or Yield Point), keuletan (Ductility), modulus elastis dari material, kelentingan dari suatu material dan ketangguhan (Hardness). Seiring dengan berkembangnya teknologi, maka pada saat ini mesin uji tarik dilengkapi dengan perangkat-perangkat elektronik untuk memudahkan dalam menganalisa data yang diperoleh. Load Cell merupakan salah satu perangkat elektronik yang digunakan sebagai perangkat tambahan pada mesin ujitarik. Load Cell menggunakan sistem perangkat pengolahan data. Karena bagaimanapun juga faktor manusia sangat dominan untuk memperoleh hasil dari pengujian ini. Tujuan dari penelitian ini adalah menentukan dan menganalisa tegangan maksimum material pada suatu spesimen benda uji berupa gaya tarik, tegangan, tegangan dan kurva uji tarik dari hasil pengujian tarik pada spesimen baja.

Salah satu hal yang bisa menyebabkan kegagalan pada elemen sebuah konstruksi mesin adalah beban yang bekerja pada elemen mesin besarnya melebihi kekuatan material. Kekuatan merupakan sifat yang dimiliki oleh setiap material. Kekuatan pada material dibagi menjadi dua bagian yaitu kekuatan tarik dan kekuatan mulur. Kekuatan material bisa diperoleh dari sebuah pengujian yang dikenal dengan nama uji tarik. Dari pengujian itu selain diperoleh specimen kerja yang putus karena proses penarikan, juga dihasilkan sebuah kurva uji tarik. Kurva ini merupakan gambaran dari proses pembebanan pada specimen kerja mulai dari awal penarikan hingga specimen kerja itu putus. Hal-hal yang perlu diperhatikan agar pengujian menghasilkan nilai yang valid adalah bentuk dan dimensi spesimen uji, pemilihan grips dan lain-lain.

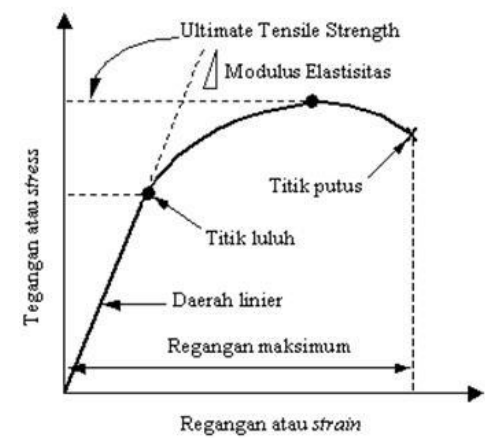

Gambar 1. Grafik Regangan terhadap Tegangan

Mesin uji tarik adalah mesin yang digunakan untuk melakukan pengujian spesimen (bahan), dengan cara menarik spesimen tersebut hingga putus. Hasil uji tarik tersebut merupakan fenomena hubungan antara tegangan dan regangan (stress strain) yang terjadi selama proses uji tarik dilakukan. Mesin uji tarik sering diperlukan dalam kegiatan engineering untuk mengetahui sifat-sifat mekanik suatu material.

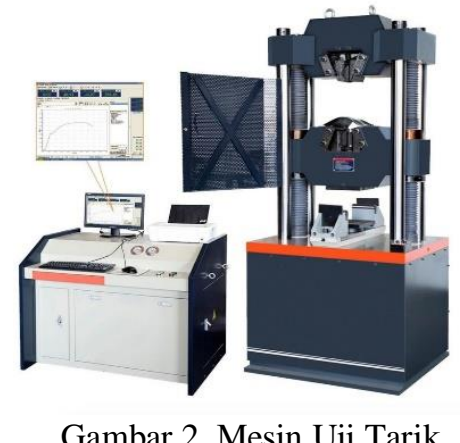

Kait (hook) berfungsi sebagai alat dimana beban dapat bergantung atau alat untuk menggantung beban. Terdapat terdapat dua pengait yang dapat dinaikkan maupun diturunkan oleh tali baja yang digulung pada dua 
buah drum melalui system puli. Pengangkatan kait dapat dilakukan secara serentak (Bersamasama) ataupun secara terpisah (sendiri-sendiri). Drum diputar oleh motor listrik yang digerakan dengan system transmisi daya. Untuk menghentukan putaran motor listrik dan mejaga beban tetap pada ketinggian tertentu maka unit katrol ini dilengkapi dengan system pengereman elektris.

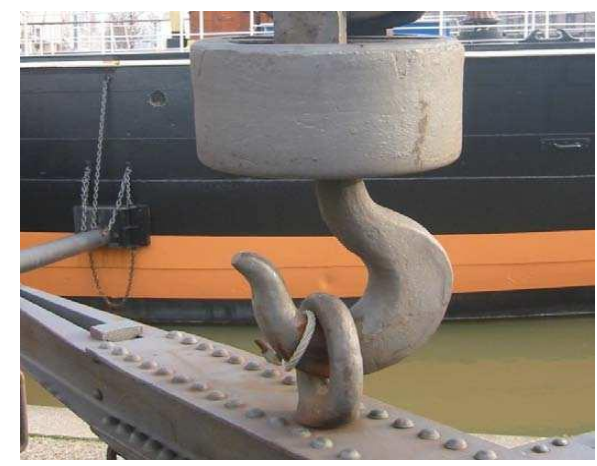

Gambar 3. Kait (Hook)

Perancangan hook harus diperhitungkan secara detail mengenai faktor keamanannya, pemakaian hook yang dirancang kurang baik akan berakibat fatal pada penggunaan dilapangan. Untuk itu perlu dilakukan analisis kekuatan hook crane tersebut dengan simulasi elemen hingga menggunakan perangkat lunak elemen hingga untuk merancang hook dengan bentuk penampang material yang tepat agar menghasilkan hook yang aman dan efisien.

\subsection{Prinsip Kerja Overhead Crane}

Overhead Crane merupakan gabungan mekanisme pengangkat secara terpisah dengan rangka untuk mengangkat sekaligus memindahkan muatan yang dapat digantungkan secara bebas atau dikaitkan pada crane itu sendiri.

Overhead travelling crane selain berfungsi sebagai alat pengangkat, juga berfungsi sebagai alat pemindah barang walaupun barang yang dipindahkan terbatas hanya pada lingkungan yang tidak terlalu luas (dalam ruangan). Tetapi overhead travelling crane sangat efektif bekerjanya karena gerakannya dapat maju-mundur dan ke kiri-ke kanan.

Banyak girder yang digunakan dan disesuaikan dengan kebutuhan dari crane tersebut. Overhead travelling crane dapat dibuat single girder maupun double girder. Girder dengan konstruksi rangka batang saat ini jarang digunakan dalam pemakaian overhead travelling crane, yang paling banyak digunakan adalah girder dengan bentuk beam atau kotak, yang dinilai lebih praktis baik dari segi konstruksi maupun bentuknya. Secara teknologi perancangan dan pembuatan overhead travelling crane ini tidak memerlukan teknologi yang terlalu tinggi seperti halnya dalam pembuatan kendaraan (otomotif).

Pada alat pengangkat yang perlu diperhatikan adalah faktor keamanan dan keselamatan kerja dari alatnya sendiri maupun terhadap operator yang menggunakan.

Dalam merencanakan konstruksi girder overhead travelling crane ini tergantung dari sarat yang harus dipenuhi untuk kebutuhannya. Hal tersebut dimaksudkan untuk memperoleh kondisi yang efisien dan peralatan yang efektif.

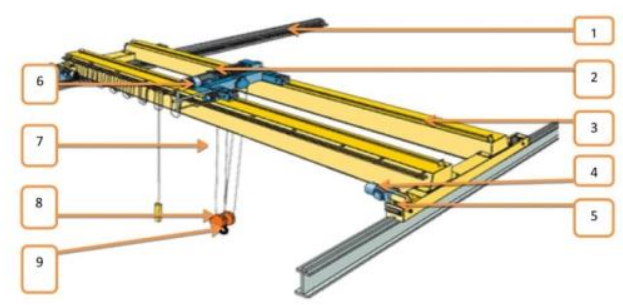

Gambar 4. Over Head Crane

Prinsip kerja pesawat angkat ini adalah untuk mengangkat menurunkan dan memindahkan alat atau pun benda berat yang ada di workshop ketika diadakan perbaikan maupun perawatan terhadap alat berat Dalam pengoperasiannya, benda yang akan diangkat harus bebas dari segala rintangan agar dapat dengan mudah diletakan sesuai dengan posisinya. Dalam pengoperasian pesawat angkat ini ada 2 macam:

1. Secara manual: Yang dilakukan oleh manusia

2. Secara Otomatis: Yang dilengkapi dengan motor penggerak (motor baker bensin uap motor listrik dan lain sebagainya).

Pesawat angkat kebanyakan memindahkan beban atau muatan bersifat jarak pendek. Dalam prakteknya biasa dicapai, dibatasi antara 10 meter sampai dengan 100 meter. Pergerakan crane pada overhead crane ada tiga jenis antara lain:

1. Gerakan Hoist (Naik/Turun)

Gerakan ini adalah gerakan naik/turun beban yang telah dipasang pada kait diangkat atau diturunkan dengan menggunakan drum, dalam hal ini putaran drum disesuaikan 
dengan drum yang sudah direncanakan. Drum digerakkan oleh motor listrik dan gerakan drum, dihentikan dengan rem sehingga beban tidak akan naik atau turun setelah posisi yang ditentukan sesuai dengan yang direncanakan.

2. Gerakan Transversal

Gerakan ini adalah berpindah arah melintang. Untuk gerakan tersebut diperlukan motor troli, dimana motor troli ini akan bergerak pada gelagar utama. Jarak pemindahan bahan dapat diatur sesuai yang diinginkan. Rem pengontrol dipasang pada poros motor dan bekerja menurut prinsip electromagnet.

3. Gerakan Longitudinal

Gerakan ini adalah gerakan memanjang (longitudinal) disepanjang rel yang terdapat dilokasi dimana portal crane berada. Gerakan ini diperoleh dengan pemakaian motor ke roda jalan.

\subsection{Autodesk Inventor}

Autodesk Inventor adalah program pemodelan solid berbasis fitur parametrik, artinya semua objek dan hubungan antargeometri dapat dimodifikasi kembali meski geometrinya sudah jadi, tanpa perlu mengulang lagi dari awal. Hal ini sangat memudahkan kita ketika sedang dalam proses desain suatu produk atau rancangan. Untuk membuat suatu model 3D yang solid ataupun surface, kita harus membuat sketsanya terlebih dahulu atau mengimport gambar 2D dari Autodesk Autocad. Setelah gambar atau model 3D tersebut jadi, kita dapat membuat gambar kerjanya menggunakan fasilitas drawing.

Autodesk Inventor juga mampu memberikan simulasi pergerakan dari produk yang kita desain serta mempunyai alat untuk menganalisis kekuatan. Dengan demikian, selain biaya yang harus kita keluarkan akan berkurang, time to market dari benda yang kita desain pun dapat dipercepat karena kita sudah mensimulasikan terlebih dahulu benda yang kita desain di komputer sebelum masuk ke proses produksi.

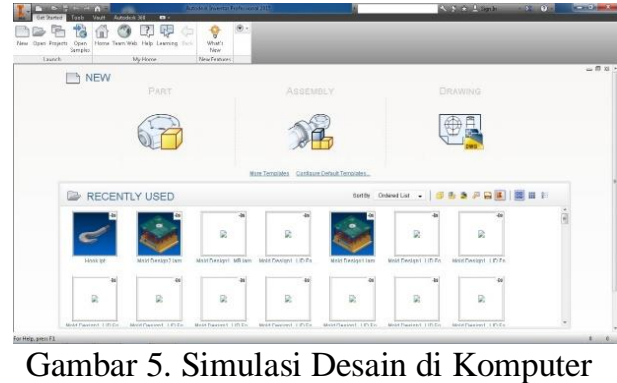

\subsection{Bahan Penelitian}

1. Spesimen

Spesimen adalah bahan yang digunakan penulis untuk melakukan pengujian secara langsung. Karna bahan yang akan diuji adalah jenis Besi Cor Nodular (FCD) maka spesimen pejal yang digunakan. Spesimen pejal berbentuk bulat dengan diameter Grip yaitu $25 \mathrm{~mm}$ dengan panjang $109 \mathrm{~mm}$ dan diameter pada Face Selection adalah 12.5 $\mathrm{mm}$ dengan panjang $60 \mathrm{~mm}$ dengan radius $12.5 \mathrm{~mm}$.

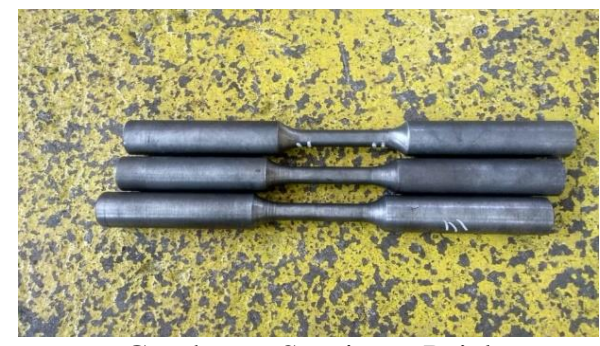

Gambar 6. Spesimen Pejal

2. Material FCD-50

Klasifikasi material FCD dimulai FCD 37, 40, 50, 60, 70 dan 80, angka dibelakang FCD menunjukkan besarnya kekuatan tarik dari Nodular Cast Iron. FCD-50 artinya besi tuang nodular yang memiliki kekuatan tarik $50 \mathrm{Kg} / \mathrm{mm}^{2}$. Adapun interpretasi dari $50 \mathrm{~kg} / \mathrm{mm}^{2}$ adalah setiap luasan $1 \mathrm{~mm}^{2}$ pada besi cor nodular mampu menahan beban tarik maksimal $50 \mathrm{Kg} / \mathrm{FCD}-50$ ini adalah as-cast, sebagai objek penelitian.

Tabel 1. Hasil Objek Penelitian

\begin{tabular}{ccccc}
\hline \multirow{2}{*}{ NO } & \multirow{2}{*}{ Kualitas } & Kuat Tarik & Elongasi & Kekerasan \\
\cline { 3 - 5 } & & Kgf/N/mm & $(\%)$ & $(\mathrm{BHN})$ \\
\hline 1 & FCD 37 & 37 & $17 \mathrm{~min}$ & $179 \mathrm{maks}$ \\
2 & FCD 40 & 40 & $12 \mathrm{~min}$ & $201 \mathrm{maks}$ \\
3 & FCD 45 & 45 & $10 \mathrm{~min}$ & $143 \mathrm{~s} / \mathrm{d} \mathrm{217}$ \\
4 & FCD 50 & 50 & $7 \mathrm{~min}$ & $170 \mathrm{~s} / \mathrm{d} \mathrm{241}$ \\
5 & FCD 60 & 60 & $3 \mathrm{~min}$ & $192 \mathrm{~s} / \mathrm{d} \mathrm{269}$ \\
6 & FCD 70 & 70 & $2 \mathrm{~min}$ & $229 \mathrm{~s} / \mathrm{d} \mathrm{302}$ \\
7 & FCD 80 & 80 & $2 \mathrm{~min}$ & $248 \mathrm{~s} / \mathrm{d} \mathrm{352}$ \\
\hline
\end{tabular}




\subsection{Alur Pengujian Langsung}

1. Cek kesiapan Alat Uji Tarik

Untuk melakukan pengujian uji tarik, kesiapan alat uji harus di cek terlebih dahulu seperti yang nampak pada gambar dibawah ini:

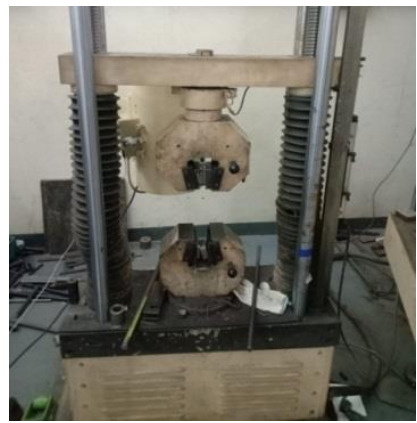

Gambar 7. Alat Uji Tarik

2. Pasangkan Spesiment pada Chuck (pencekam)

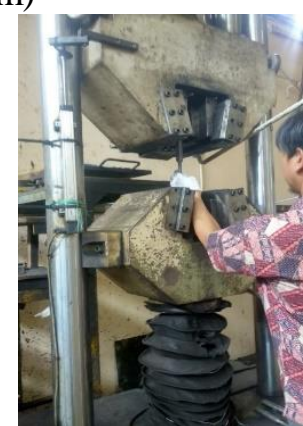

Gambar 8. Chuck Pencekam

3. Pengujian ke 1 sampai Spesiment tersebut putus.

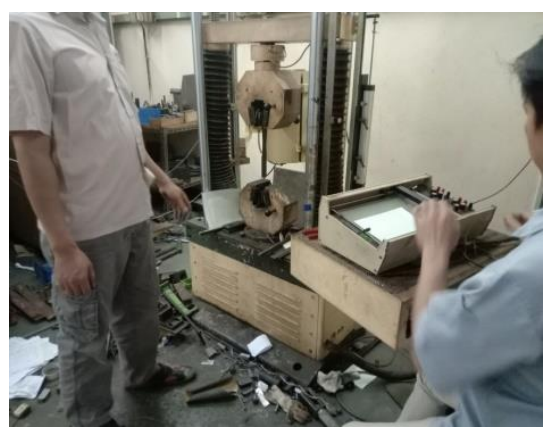

Gambar 9. Pengujian ke 1

4. Pengujian ke 2 sampai Spesiment tersebut putus.

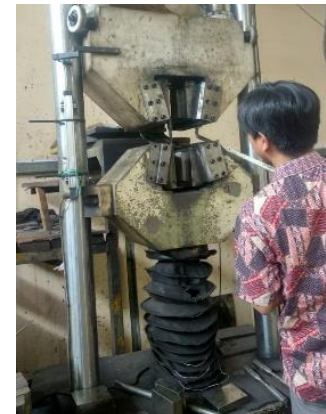

Gambar 10. Pengujian ke 2

5. Pengujian ke 3 sampai Spesiment tersebut putus.

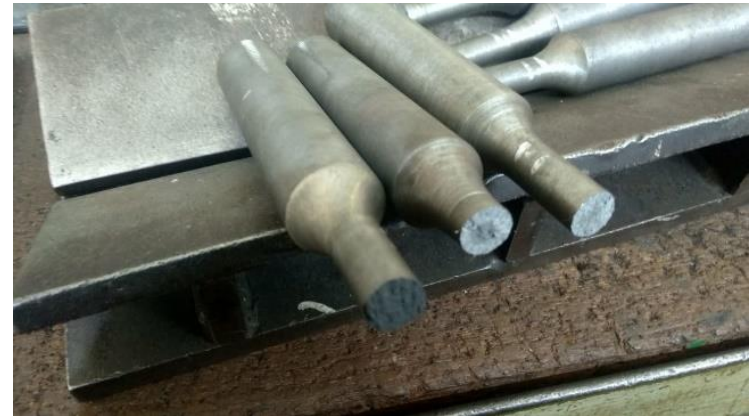

Gambar 11. Pengujian ke 1

6. Lepas spesimen dari ragum dan mulai lakukan pengambilan data setelah spesimen putus.

7. Pengamatan dan kesimpulan hasil dari pengujian tarik dari speciment tersebut.

\subsection{Alur Simulasi Pengujian Tarik}

1. Desain Spesimen

Langkah awal dalam melakukan simulasi uji tarik dengan software ini adalah melakukan pembuatan gambar spesimen,dengan dimensi yang sudah ditentukan pihak penguji dan melakukan proses pembentukan 3d dengan menu extrude.

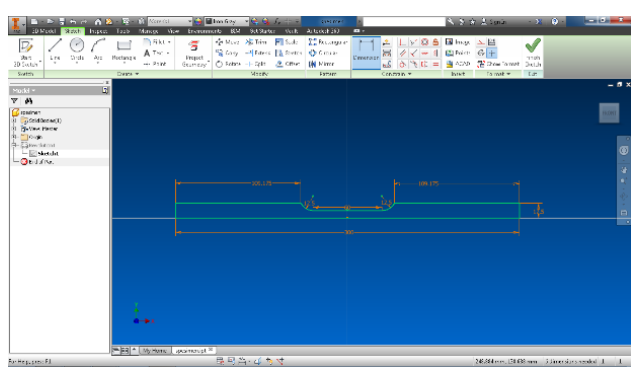

Gambar 12. Desain Spesimen

2. Menentukan Jenis Material 
Setelah selesai membuat bentuk $3 \mathrm{~d}$ dari spesimen masuk ke toolbar Stress Analysis yang ada pada menu Environments

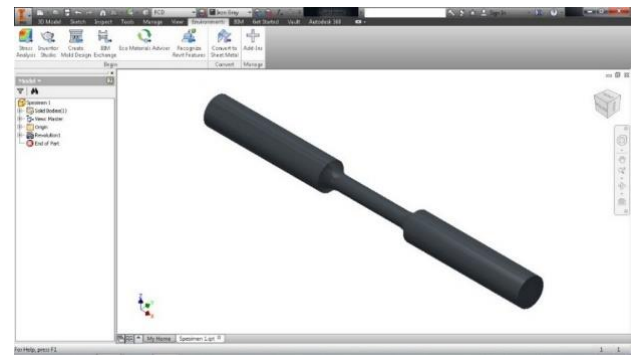

Gambar 13. Stress Analysis

3. Menentukan Material dan Faktor Keamanan

Menentukan Material dan jenis pengujian yang akan dilakukan dengan menekan Tools Assign. Kemudian tentukanlah material yang akan di uji dan memilih jenis Faktor keamanan Ultimate Tensile Strength

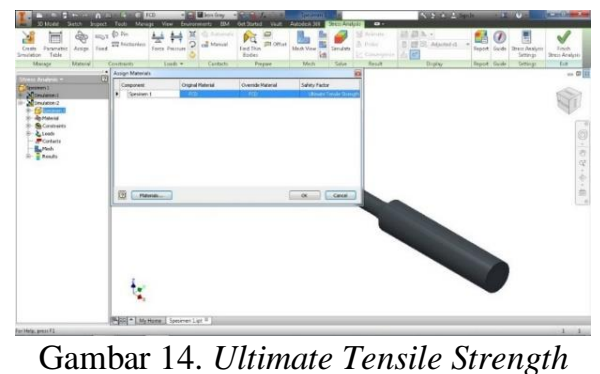

4. Menentukan area cekam

Tahap selanjutnya adalah menentukan area cekam pada spesimen dengan menekan tools Fix Contrain, area yang dipilih sebagai area cekam hanya satu sisi grip saja agar mendapat kemuluran dari spesimen tersebut.

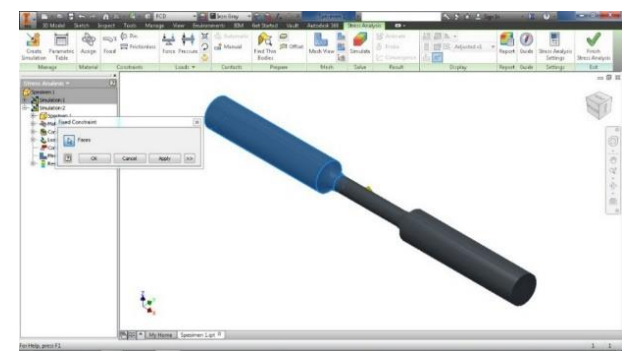

Gambar 15. Area Cekam

5. Area pembebanan dan besar pembebanan menentukan titik pembebanan dan besar pembebanan dengan menekan area yang akan diberikan pembebanan.

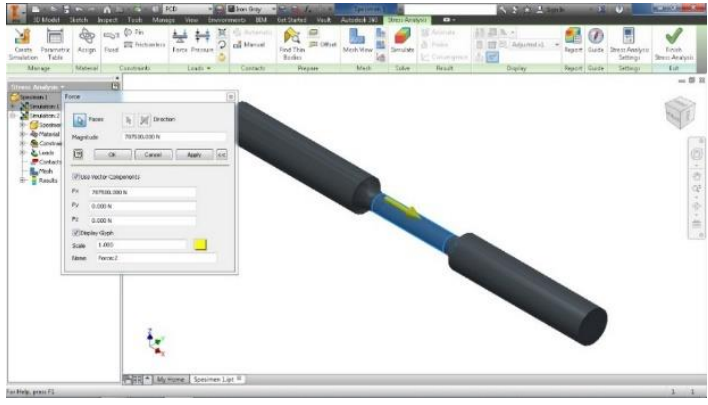

Gambar 16. Area Pembebanan

6. Simulasi Uji Tarik

Setelah itu adalah melakukan simulasi uji tarik dengan menekan tools Simulate, tunggu sampai proses selesai.
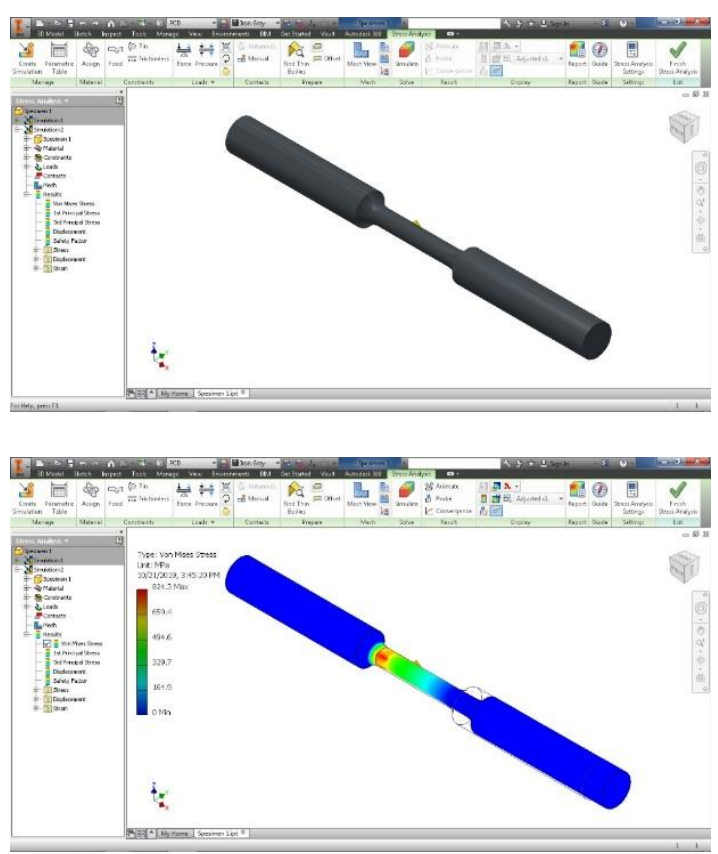

Gambar 17. Simulasi Uji Tarik

7. Data Simulasi Uji Tarik

Dengan menekan tool Report kita dapat melihat data hasil dari simulasi pengujian tarik

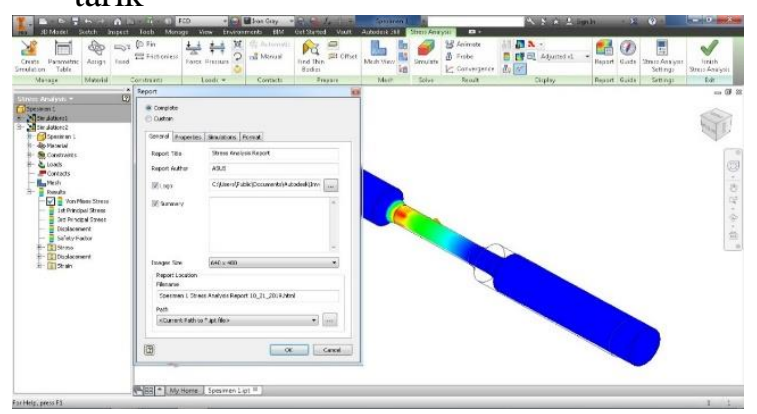




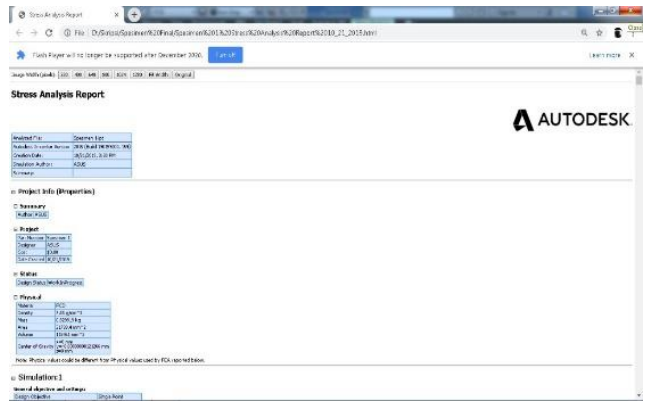

Gambar 18. Tool Report Uji Tarik

\section{Hasil dan Pembahasan}

\subsection{Hasil Pengujian Tarik Langsung}

Dari hasil percobaan pengujian tarik yang telah dilakukan di BPPT/Balai Besar Teknologi Kekuatan Struktur, didapatkan kurva dan datadata sebagai berikut:

1. Kurva Hasil Uji Tarik:

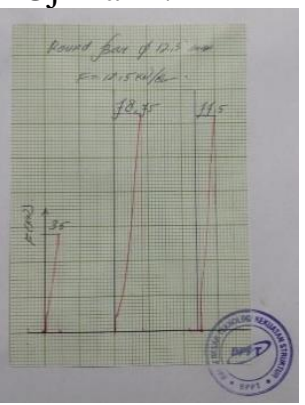

Gambar 19. Grafik Uji Tarik

2. Bentuk Patahan Pengujian Tarik

Setelah dilakukan pengujian tarik spesimen 1, 2 dan 3 didapatkan bentuk patahan pada titik yang sama. pada spesimen 1 titik patah pada luas penampang. pada spesimen 2 titik patah pada luas penampang. pada spesimen 3 titik patah pada luas penampang.

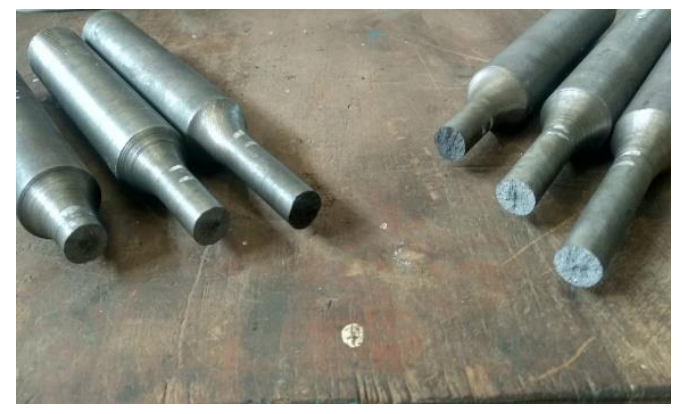

Gambar 20. Bentuk Patahan Uji Tarik

\subsection{Analisa Hasil Pengujian}

Dari data hasil pengujian tarik pada spesimen material FCD-50 untuk pembuatan hook Crane, dapat dihitung:

1. Tegangan Maksimum.

2. Regangan Maksimum.

a. Spesimen 1

$$
\begin{aligned}
& \text { Dik : Ao }=121 \\
& \Delta \mathrm{L}=10.0 \mathrm{~mm} \\
& \text { Lo }=300 \mathrm{~mm}
\end{aligned}
$$

Dit : $\sigma_{\mathrm{u}} \ldots \ldots . . ?$

E..........?

Jawab :

1. $\sigma_{\mathrm{u}}=\frac{34.9 \mathrm{KN}}{121 \mathrm{~mm}^{2}}$

$$
=288.6 \mathrm{~N} / \mathrm{mm}^{2}
$$

2. $\varepsilon=\frac{\Delta \mathrm{L}}{\mathrm{Lo}} \times 100 \%$

$\varepsilon=\frac{10}{300} \times 100 \%$

$\varepsilon=3.3 \%$

Dari perhitungan ini didapatkan Tegangan tarik maksimum pada spesimen 1 sebesar $288.6 \mathrm{~N} / \mathrm{mm}^{2}$ dan pertambahan panjang sebesar $10 \mathrm{~mm}$ atau $3.3 \%$

b. spesimen 2

Dik : Ao $=121$

$$
\begin{aligned}
\Delta \mathrm{L} & =5.2 \mathrm{~mm} \\
\mathrm{Lo} & =300 \mathrm{~mm}
\end{aligned}
$$

Dit $: \sigma_{\mathrm{u}} \ldots \ldots$ ?

E...........?

jawab :

1. $\sigma_{\mathrm{u}}=\frac{78.4 \mathrm{KN}}{122 \mathrm{~mm}^{2}}$

$\sigma_{\mathrm{u}}=643.1 \mathrm{~N} / \mathrm{mm}^{2}$

2. $\varepsilon=\frac{\Delta \mathrm{L}}{\mathrm{Lo}} \times 100 \%$

$\varepsilon=\frac{5.2}{300} \times 100 \%$

$\varepsilon=1.7 \%$

Dari perhitungan ini didapatkan Tegangan tarik maksimum pada spesimen 2 sebesar $643.1 \mathrm{~N} / \mathrm{mm}^{2}$ dan pertambahan panjang sebesar $5.2 \mathrm{~mm}$ atau $1.7 \%$

c. Perhitungan tegangan tarik maksimum pada spesimen 3

$$
\begin{aligned}
& \text { Dik : } A o=121 \\
& \Delta \mathrm{L}=5.4 \mathrm{~mm} \\
& \mathrm{Lo}=300 \mathrm{~mm}
\end{aligned}
$$




$$
\begin{aligned}
& \text { Dit }: \sigma_{\mathrm{u}} \ldots \ldots \ldots ? \\
& \varepsilon \ldots \ldots \ldots . ? \\
& \text { Jawab }: \\
& \text { 1. } \sigma_{\mathrm{u}}=\frac{77.5 \mathrm{KN}}{121 \mathrm{~mm}^{2}} \\
& \sigma_{\mathrm{u}}=641 \mathrm{~N} / \mathrm{mm}^{2} \\
& \text { 2. } \varepsilon=\frac{\Delta \mathrm{L}}{\mathrm{LO}} \times 100 \% \\
& \varepsilon=\frac{5.4}{300} \times 100 \% \\
& \varepsilon=1.8 \%
\end{aligned}
$$

Dari hasil perhitungan ini didapat tegangan tarik maksimum pada spesimen 3 adalah 641 $\mathrm{N} / \mathrm{mm}^{2}$ dan pertambahan panjang sebesar $5.4 \mathrm{~mm}$ atau $1.8 \%$.

\subsection{Pembahasan Hasil Pengujian}

Pada percobaan uji tarik ini, menggunakan Material FCD-50 yang dibuat menjadi 3 spesimen, Proses pengujiannya adalah dengan cara memasangkan spesimen pada alat uji tarik. Dengan gaya yang sudah ditentukan pengujian dilakukan sampai terjadi fracture (patah) dapat diketahui kekuatan maksimum uji tarik yaitu pada spesimen 2 dengan beban tarik $78.4 \mathrm{kN}$

\begin{tabular}{|c|c|c|}
\hline Name & Minimum & Maximum \\
\hline Volume & $118461 \mathrm{~mm}^{3}$ & \\
\hline Mass & $0,929919 \mathrm{~kg}$ & \\
\hline $\begin{array}{ll}\text { Von } & \text { Mises } \\
\text { Stress } & \end{array}$ & $0,0000014 \mathrm{Mpa}$ & 833,833 Мpa \\
\hline $\begin{array}{l}\text { Principal } \\
\text { Stress }\end{array}$ & $-0,226676 \mathrm{Mpa}$ & 943,249 Мра \\
\hline
\end{tabular}
kuat tarik $643.1 \mathrm{~N} / \mathrm{mm}^{2}$ dan $6431 \mathrm{Kgf} / \mathrm{cm}^{2}$.

\subsection{Simulasi Uji Tarik}

Dari proses simulasi uji tarik dengan menggunakan Software Autodesk inventor didapatkan data-data sebagai berikut:

Tabel 2. Hasil Simulasi Software Autodesk Inventor

1. Von Mises Stress

Von Mises dapat dikatakan gagal, jika nilai maksimum Von Mises stress material lebih dari maksimum tegangan tarik.

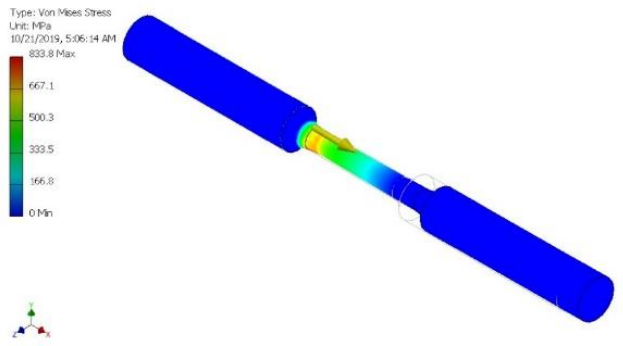

Gambar 21. Von Mises Stress

2. Principal Stress

Principal Stress akan membantu kita memahami maksimum tegangan tarik (tensile) dengan penambahan dari nilai faktor keamanan akibat adanya pembebanan.

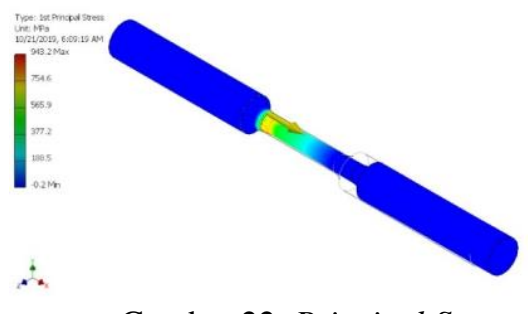

Gambar 22. Principal Stress

3. Safety Factor (Faktor Keamanan)

Faktor keamanan adalah faktor yang digunakan untuk mengevaluasi keamanan suatu struktur, dimana kekuatan suatu bahan harus melebihi kekuatan sebenarnya (Hearn, 1997).

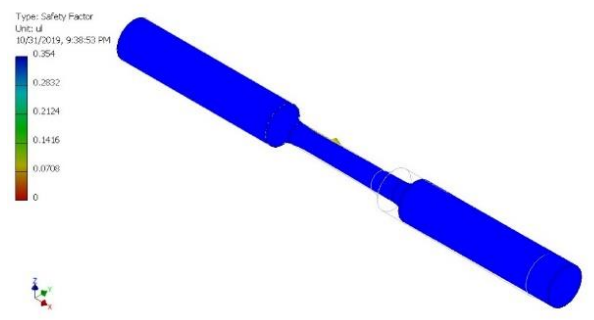

Gambar 23. Safety Factor

Faktor Keamanan $(\mathrm{n})=\frac{s y}{\sigma \mathrm{e}}$

Dimana, $\mathrm{n}$ : Faktor Kemanan

$\mathrm{S}_{\mathrm{y}}$ : Yield Strength

$\sigma \mathrm{e}$ : Tegangan Von Mises

Sehingga,

$$
\begin{aligned}
& \mathrm{n}=\frac{295}{833.833} \times 100= \\
& \mathrm{n}=0.354 \text { atau } 35.4 \%
\end{aligned}
$$




\section{Perhitungan tegangan tarik maksimum pada simulasi pengujian tarik}

Dik : $1^{\text {St }}$ Principal Stress $=943.249 \mathrm{~N} / \mathrm{mm}^{2}$, (Sumber:Autodesk Inventor 2015)

Faktor keamanan $(\mathrm{n})=0.354$

Dit : Tegangan Tarik Maksimum $\left(\sigma_{\mathrm{u}}\right) \ldots \ldots .$. ?

$\sigma_{\mathrm{u}}=943.249 \times 0.354=334 \mathrm{~N} / \mathrm{mm}^{2}$

$\sigma_{\mathrm{u}}=943.249-334=609.25 \mathrm{~N} / \mathrm{mm}^{2}$

Jadi tegangan tarik maksimum tanpa faktor keamanan pada simulasi pengujian tarik sebesar $609.25 \mathrm{~N} / \mathrm{mm}^{2}$

\subsection{Perbandingan Hasil Pengujian Langsung Dan Pengujian Menggunakan Software Autodesk Inventor}

Berdasarkan data uji tarik yang telah dilakukan menggunakan software Autodesk Inventor dan uji tarik secara langsung di BPPT Puspiptek. Diperoleh data Tegangan tarik maksimum menggunakan software Autodesk Inventor sebesar $609.25 \mathrm{~N} / \mathrm{mm}^{2}$ dengan pembebanan sebesar $78.75 \mathrm{kN}$, sedangkan hasil uji tarik secara langsung diperoleh data sebesar 643.1 $\mathrm{N} / \mathrm{mm}^{2}$ dengan pembebanan yang sama yaitu sebesar $78.75 \mathrm{kN}$. Sehingga dapat disimpulkan dari dua pengujian tersebut, dapat dikatakan sudah sesuai dengan data perencanaan yang telah dilakukan sebelumnya dengan faktor keamanan sebesar 0.354 atau $35.4 \%$

\section{Kesimpulan}

Dari analisa dan pembahasan tentang kekuatan material FCD-50 untuk peembuatan hook crane pada alat uji tarik, dapat diambil beberapa kesimpulan, yaitu sebagai berikut:

1. Berdasarkan hasil uji tarik material FCD-50 pada spesimen 2, diketahui tegangan maksimum yaitu sebesar $643.1 \mathrm{~N} / \mathrm{mm}^{2}$ dengan beban tarik $78.75 \mathrm{kN}$.

2. Sedangkan untuk mengetahui hasil dari uji tarik spesimen material FCD-50 sebagai langkah awal pendesainan hook crane yaitu dengan cara melakukan simulasi uji tarik menggunakan software Autodesk Inventor didapatkan tegangan maksimum sebesar $609.25 \mathrm{~N} / \mathrm{mm}^{2}$ dengan beban tarik $78.75 \mathrm{kN}$.

Dari data yang dihasilkan dari kedua metode pengujian tersebut, diketahui bahwa Software Autodesk Inventor sebagai software penyedia simulasi uji tarik memiliki tingkat keakurasian data mencapai $94.7 \%$, angka ini didapat dengan acuan dari pengujian langsung di bpptb puspiptek.

\section{Daftar pustaka}

Al Ichlas Imran, Kadir.2017. Simulasi Tegangan Von Mises dan Analisa Safety Factor Gantry Crane Kapasitas 3 Ton. Vol 8.

Anggi Kurniawan.2014. Analisa Kekuatan Struktur Crane Hook Dengan Perangkat Lunak Elemen Hingga Untuk Pembebanan $20 \quad$ Ton.Bengkulu. Universitas Bengkulu.

Budhi Cahyono.2005. Perancangan Overhead Crane Kapasitas 10 Ton Dengan Metode VDI 2221.Jakarta. Universitas Mercu Buana.

Gunawan.2010. Analisis Simulasi Elemen Hingga Kekuatan Crane Hook Menggunakan Perangkat Lunak Berbasis Sumber Terbuka. Medan. Universitas Sumatra Utara.

Haris Budiman.2016.Analisis Pengujian Tarik (Tensile Test) Pada Baja ST37 Dengan Alat Bantu Ukur Load Cell. Jurnal JEnsitec.Vol 03.

Syuriansyah Sabarudin dkk.2017.Peningkatan Kekuatan Tarik Material FCD-50 Dengan Proses Austemper, Cryogenic and Temper Ductile Iron (ACTDI). Vol 3.

G Niemann, 1992, Elemen Mesin, (Anton Budiman: terjemahan), Erlangga: Jakarta.

Mott, Robert L. 2009. Elemen-Elemen Mesin dalam Perancangan Mekanis (Perancangan Elemen Mesin Terpadu) 2. Yogyakarta: Penerbit Andi.

Sato; G. Takeshi. 2000. Menggambar mesin menurut standar ISO, Cetakan ke -9. PT. Pradnya Paramita, Jakarta

Uthami,Z.A., 2010 , Solid Works Alat Bantu Merancang Komponen Mudah , modula, Bandung. 